\title{
Nutritional Value of Baobab Leaves (Adansonia digitata L.) from North- and West-Kordofan in Sudan: In-Vitro Minerals Bioavailability and Protein Quality
}

\author{
T. Y. Habte ${ }^{1, *}$, I. Suleiman ${ }^{2}$, A. I. Ahmed ${ }^{2}$, S. Latif ${ }^{3}$, M. B. Krawinkel ${ }^{1}$ \\ ${ }^{1}$ Institute of Human Nutrition, Justus-Liebig-University Giessen, Giessen, Hesse, Germany. \\ ${ }^{2}$ Department of Food Technology, University of Kordofan, El Obeid, Shimal Kurdufan, Sudan. \\ ${ }^{3}$ Institute of Agricultural Engineering, Tropics and Subtropics Group, University Hohenheim, Stuttgart, Baden-Württemberg, \\ Germany.
}

\begin{abstract}
How to cite this paper: T. Y. Habte, I. Suleiman, A. I. Ahmed, S. Latif, M. B. Krawinkel. (2021) Nutritional Value of Baobab Leaves (Adansonia digitata L.) from North- and West-Kordofan in Sudan: In-Vitro Minerals Bioavailability and Protein Quality. International Journal of Food Science and Agriculture, 5(3), 482-491.

DOI: 10.26855/ijfsa.2021.09.019
\end{abstract}

Received: June 31, 2021

Accepted: July 28, 2021

Published: August 30, 2021

*Corresponding author: T. Y. Habte, Institute of Human Nutrition, Justus-Liebig-University Giessen, Giessen, Hesse, Germany.

Email:

Tsige-Yohannes.Habte@ernaehrung.uni-gi essen.de

\begin{abstract}
Baobab leaves are rich in essential minerals and antioxidants. They are high in antinutritional molecules like phytic and tannic acids that hinder mineral absorption. Information on protein quality of baobab leaves, which is essential for the utilization of minerals in baobab leaves is scanty. In order to narrow the gap in knowledge, mineral absorption was assessed using the in-vitro bioavailability procedures. The protein quality was determined by the method of estimating indispensable amino acid score (IAAS) and refined to give digestible protein corrected amino acid score (DPCIAAS). The mean in-vitro bioavailability of calcium, magnesium and iron are found to be $31.5 \%, 59 \%, 7.5 \%$, respectively. The in-vitro bioavailability of $\mathrm{Ca}, \mathrm{Mg}, \mathrm{Zn}$ and $\mathrm{Cu}$ regressed positively $\left(\mathrm{r}^{2}=0.71\right)$ and significantly $(\mathrm{p}<0.05)$ on the levels exposed to in-vitro digestion. There was no interaction ( $>0.05$ ) between $\mathrm{Ca}$ and Mg. The average crude protein content of baobab leaves was $14.73 \%$; there was no marked ( $p>0.05)$ difference between the samples from $\mathrm{N}$ - and $\mathrm{W}-$ Kordofan. Except for cysteine, methionine, valine and tryptophan the indispensable amino acids profile for the other amino acids were significantly $(\mathrm{p}<0.05)$ higher for samples from North-Kordofan than those from West-Kordofan. The IAAS for leucine, cysteine and methionine $(0.53,0.51,0.5$, respectively) of samples from both districts was low. A mixed diet formulated based on cereals and complemented with baobab leaves and legumes could satisfy the daily requirement for indispensable amino acids and optimize mineral absorption.
\end{abstract}

\section{Keywords}

Baobab Leaves, Minerals, In-Vitro Bioavailability, Protein Quality

\section{Introduction}

Mineral concentration in foodstuffs is a worthy measure of recommended daily intake if allowances for the losses via the digestive system are attached to it. Documented evidence show that both food and human factors can influence the efficiency of absorption and utilization of minerals [1]. Plant food components such as fiber (lignocellulose), carbohydrate gums, phytochemicals including phytic-, tannic-, and oxalic acids and several thousand polyphenols that are classified under flavonoids and phenolic acids form insoluble complexes with minerals and render them unavailable [2, 3].

The problems of polyphenol-minerals complexes are of two-fold; on one side they cause mineral deficiency and on 
the other side they limit the bioavailability of food born antioxidants that could inhibit or neutralize reactive oxygen species (ROS) and expose people to oxidative damages that could cause cancer, cardiovascular- and neurodegenerative disorders $[4,5]$. Fatty acids, fructo-oligosaccharides and the interaction between minerals additionally compromise the availability of minerals [1, 2].

The bioavailability of both minerals and potentially complexing polyphenols is highly associated to the environment in the digestive lumen ( $\mathrm{pH}$, enzymes) and the matrix of the food. Food polyphenols are usually bound to carbohydrates moiety that govern the degree of digestibility. Those bound to soluble carbohydrates are more easily available for absorption [Scholz and Williamson 2007]. Plant factors like cultivar, age and yield, as well as environmental factors such as soils, climate, storage and processing determine the type and level of polyphenols [6] and their influence on mineral bioavailability.

Complex interactions between different minerals can also compromise the effectiveness of a diet in promoting growth and health. In reference to magnesium, for example, it is not only its adequacy that prove biological development but also its correct balance with dietary calcium. A high deviation of the ratio of magnesium to calcium can result in the depression of magnesium absorption and utilization [7]. A calcium to magnesium ratio of 2 is optimal whereas that of $<1.7$ or $>2.8$ can influence absorption negatively [8].

Food components such as proteins, lactose, vitamins A and C could promote the absorption of minerals. Milk proteins including casein, beta-lactoglobulin, and alfa-lactalbumin contain phosphate groups that bind $\mathrm{Ca}, \mathrm{Fe}$ and $\mathrm{Zn}$ and hinder their complexion with antinutritional molecules, leaving them soluble and absorbable in the digestive tract [9]. Fermentable oligosaccharides improve the apparent absorption of some minerals [10]. Sugar alcohols including polyols and maltols promote mineral bioavailability in rats [11]. The relative high calcium to phosphate ratio (2.2) in human milk induces more calcium absorption ( $50 \%)$ than the ratio of only 0.77 in cow’s milk with about $30 \%$ absorption [12].

Even though proteins and their hydrolytic products, peptides and amino acids, can promote mineral absorption, exaggerated consumption particularly that of poor-quality protein can enhance urinary loss and decrease mineral retention [13]. Some specific study indicates that the amino acids lysine, arginine and leucine can promote calcium absorption and bone mineral density [14]. A certain meta-analysis, additionally, documented that the consumption of adequate amount of quality protein can benefit calcium retention [15].

Baobab leaves from $\mathrm{N}$ - and $\mathrm{W}$-Kordofan as well as from other sources are potentially very rich in essential minerals $[16,17]$. Information was, however, lacking on the fraction of the minerals that could be biologically absorbed and the protein quality that could influence their utilization [2]. Therefore, it was rational to investigate the bio-availability of minerals and the protein concentration and quality of baobab leaves that were collected from the Baobab-Belt, in Northand West-Kordofan, Sudan.

\section{Materials and Methods}

Sixty shed-dried baobab leaf samples collected from randomly selected sixty trees that grow equally distributed in ten villages that belong to the two districts, North- and West-Kordofan, Sudan, were transported to the Nutrition Laboratory, Department of International Nutrition, Justus-Liebig-University Giessen, Germany. The samples were here lump-summed according to the villages of origin and thoroughly mixed. Then representative sub-samples of $25 \mathrm{~g}$ each were subjected to in-vitro digestion and dialysis following the method of equilibrium dialysis earlier described by Miller [18] and later modified and reported by Wolters et al. [19]. Aliquots of dialysate were analyzed using ICP-OES (inductive coupled plasma-optic emission spectrometer) to estimate the dialyzable $\mathrm{Ca}, \mathrm{Mg}, \mathrm{Fe}, \mathrm{Zn}, \mathrm{Cu}$ and $\mathrm{Mn}$. The in vitro-bioavailability (\%) of each mineral is calculated as: dialyzable mineral/amount mineral exposed to in vitro-digestion x 100; the result represents apparent absorbability of each mineral.

Similar batches of sub-samples were sent to the laboratory of Agricultural Engineering in the Tropics and Subtropics, University of Hohenheim, Stuttgart, Germany for the analysis of protein content and quality. The amino acid profile of each sample is compared with that of a reference protein (egg protein) to give the indispensable amino acid score (IAAS). This estimation is refined by considering the digestibility of the protein in the baobab leaves and accompanying ingredients in a diet formulated for an adult man (70 kg body weight, BMI $=20-25 \mathrm{~kg} / \mathrm{m}^{2}$ ); details are given in the results and discussions. Digestible protein corrected amino acids (DPCAAs) is given in g/g DCP (digestible crude protein), and it is compared with the amino acid requirement by an adult man.

\section{Statistical analysis}

Descriptive statistic was applied to calculate the mean values and the corresponding deviations. Significant differences between means were determined using the t-test for absolute values of proteins, amino acids and bio-available indispensable amino acids. The null-hypothesis that villages do not differ in protein composition and mineral bioavailability is tested at error term level 5\% type 1 [20]. Associations and interactions between minerals are estimated using 
tests of correlation/regression. All of the calculations are conducted using the statistical package Excel.

\section{Results and discussions}

\subsection{In-vitro bioavailability of minerals}

One important factor that influences the in-vitro bioavailability of minerals is the level exposed to in-vitro digestion. In the study at hand $25 \mathrm{~g}$ of each sub-sample was digested in-vitro. Earlier analysis indicated that the mineral concentration of baobab leaves from different trees, villages and districts varied considerably [16]. The level of every mineral in each sample exposed to in-vitro digestion was therefore the product of the mineral concentration (mg/100g) by $25 \mathrm{~g}$. Table 1 presents the mean mineral content of selected samples that were exposed to in-vitro digestion. Except for zinc, the levels of all other minerals varied significantly according to the origin of the samples (North- or W-Kordofan), p-values are given at the last column of Table 1.

Table 1. The average level of minerals $(\mathrm{mg} \pm \mathrm{SE})$ exposed to in-vitro digestion

\begin{tabular}{cccc}
\hline Minerals & N-Kordofan & W-Kordofan & P-value \\
\hline $\mathrm{Ca}$ & $615 \pm 183$ & $811 \pm 496$ & $\mathrm{P}<0.05$ \\
$\mathrm{Mg}$ & $163 \pm 27.2$ & $115 \pm 13.2$ & $\mathrm{p}<0.001$ \\
$\mathrm{Fe}$ & $12.33 \pm 0.22$ & $8.87 \pm 0.32$ & $\mathrm{p}<0.05$ \\
$\mathrm{Zn}$ & $0.52 \pm 0.001$ & $0.45 \pm 0.001$ & $\mathrm{p}>0.05$ \\
$\mathrm{Cu}$ & $0.403 \pm 0.0$ & $0.3 \pm 0.001$ & $\mathrm{P}<0.05$ \\
$\mathrm{Mn}$ & $1.417 \pm 0.008$ & $0.112 \pm 0.0$ & $\mathrm{p}<0.001$ \\
\hline
\end{tabular}

Unlike the variabilities in the level of minerals, it is only iron and manganese that show significant $(\mathrm{p}<0.05)$ differences in the in-vitro bioavailability between the samples collected from $\mathrm{N}-\& \mathrm{~W}$-Kordofan (Table 2). In the case of both iron and manganese, higher values are recorded for samples from W-Kordofan probably because of the inverse impact of the lower $(\mathrm{p}<0.05)$ levels of both minerals in the analyzed leaf samples (Table 1$)$. As there is no significant district effect on the in-vitro bioavailability of the other minerals, the cumulative averages (Table 2) could be valid representative.

Table 2. Mean in-vitro bioavailable minerals* in baobab leaves from N- \& W-Kordofan, Sudan

\begin{tabular}{|c|c|c|c|c|c|c|c|}
\hline Districts & Villages & $\mathrm{Ca}$ & $\mathrm{Mg}$ & $\mathrm{Fe}$ & $\mathrm{Zn}$ & $\mathrm{Cu}$ & Mn \\
\hline \multirow[t]{6}{*}{ N. Kordofan } & Eldajo & 0.288 & 0.751 & 0.055 & 0.2 & 0.334 & 0.044 \\
\hline & Elarit & 0.336 & 0.617 & 0.053 & 0.18 & 0.418 & 0.14 \\
\hline & Fawri & 0.306 & 0.556 & 0.061 & 0.19 & 0.324 & 0.254 \\
\hline & Eldigail & 0.262 & 0.541 & 0.064 & 0.29 & 0.264 & 0.218 \\
\hline & Elgama & 0.307 & 0.623 & 0.061 & 0.29 & 0.364 & 0.182 \\
\hline & Mean & $0.300 \pm 0.027$ & $0.618 \pm 0.083$ & $0.059 \pm 0.004$ & $0.23 \pm 0.005$ & $0.341 \pm 0.056$ & $0.168 \pm 0.081$ \\
\hline \multirow[t]{6}{*}{ W. Kordofan } & Nashrbu & 0.330 & 0.599 & 0.081 & 0.21 & 0.342 & 0.436 \\
\hline & Sbihat & 0.396 & 0.631 & 0.083 & 0.22 & 0.360 & 0.648 \\
\hline & Jkhisat & 0.320 & 0.609 & 0.098 & 0.18 & 0.338 & 0.532 \\
\hline & Umejija & 0.319 & 0.586 & 0.094 & 0.16 & 0.400 & 0.344 \\
\hline & Khiri & 0.285 & 0.546 & 0.059 & 0.11 & 0.282 & 0.276 \\
\hline & Mean & $0.330 \pm 0.041$ & $0.594 \pm 0.031$ & $0.083 \pm 0.015$ & $0.18 \pm 0.004$ & $0.344 \pm 0.043$ & $0.447 \pm 0.148$ \\
\hline Cumulative average & & $0.315 \pm 0.036$ & $0.585 \pm 0.060$ & $0.075 \pm 0.017$ & $0.2 \pm 0.005$ & $0.344 \pm 0.047$ & $0.361 \pm 0.133$ \\
\hline P-value & & & & $\mathrm{p}<0.05$ & & & $\mathrm{p}<0.05$ \\
\hline
\end{tabular}

*For purposes of accuracy in statistical analysis, in-vitro bioavailability is given in absolute terms, i.e., 0.288 for Ca from Eldajo instead of $28.8 \mathrm{~g} / 100 \mathrm{~g}$ or $28.8 \%$. 

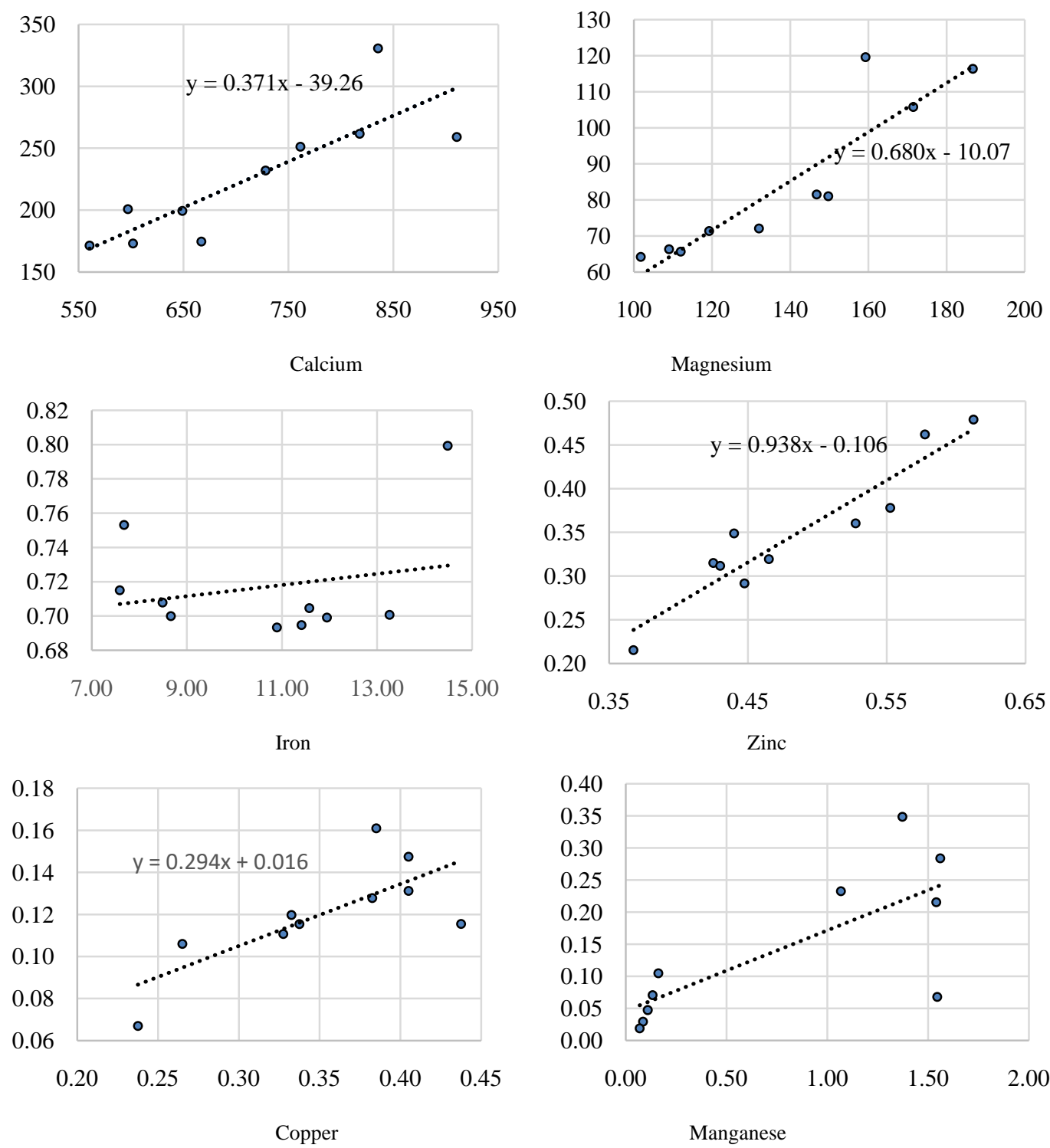

Figure 1. Dependency of in-vitro bioavailable mineral (mg) on the level exposed to in-vitro digestion; $\mathrm{X}$-axis = mineral (mg) in baobab leaves exposed to digestion; $\mathrm{Y}$-axis = in-vitro bioavailable mineral (mg).

It is recorded that the bioavailability of minerals increases with increased ingestion until the level of adequacy, and slows down thereafter [12]. The results of our study regarding the association of the in-vitro bioavailability of each mineral with corresponding level in the leaf-samples exposed to digestion is shown in Figure 1. Accordingly, the in-vitro bioavailability of $\mathrm{Ca}, \mathrm{Mg}, \mathrm{Zn}$ and $\mathrm{Cu}$ regress positively $\left(\mathrm{r}^{2}=0.71 ; 0.82 ; 0.77 ; 0.55\right.$, respectively) and significantly $(p<0.05)$ at the level of each mineral in the leave samples exposed to digestion. The level of calcium exposed to in-vitro digestion is within the limits of daily requirement for adults while that of magnesium, zinc and copper are below the requirement. Even though the level of manganese is way below the requirement, the tendencies are inconclusive and insignificant $(\mathrm{p}>0.05)$. Iron behaved quite different from the other minerals in that the in-vitro bioavailability does not regress on the amount exposed to digestion. Regression equation was, therefore, meaningless for both manganese and iron.

In conditions where the iron supply is within the domain of daily requirement, the low level of in-vitro bioavailability (5-10\%) could implicate the interference of inherent food factors. An earlier study with a diet consisting of cereals and legumes characterized by a total of $1 \%$ phytic acid resulted in very low iron absorption; but, decreasing the phytic acid by $90 \%$ increased the absorption by 2 to 5 -fold [21]. Another evidence testifies that a negative influence of soy protein supplement in the absorption of iron, zinc and calcium may not only be due to increased level of phytic acid but also due to trypsin inhibitor in the soy protein [24]. In comparison to plant protein supplements (vegetables), animal protein 
supplement promotes better dietary minerals absorption, probably due to the quality of protein, which is dependent on the amino acid composition [21, 22, 23].

\subsection{The concentration and quality of proteins in the baobab leaves}

The characterization of baobab leaves based on the levels and quality of protein is important for the formulation of complete diets that enable efficient utilization of nutrients for normal growth and body maintenance. Dietary and body proteins consist of at least twenty amino acids, half of which can be synthesized in the body in standard dietary condition. The rest ten amino acids (essential or indispensable amino acids) have to be delivered with the protein of the daily diet, otherwise protein synthesis in the body can be interrupted causing stunting, wasting, susceptibility to infection, loss of physical and mental strength and power [25]. The proteins that contain all of the indispensable amino acids in the amount required by the body are classified as quality protein. Proteins of animal origin [egg albumin, milk protein casein, chicken breast) exemplify high quality protein [26]. In contrast, the proteins from food ingredients of plant origin are incomplete, they are variably deficient in a few of the indispensable amino acid. In general, cereals are deficient in lysine while legumes are inadequate in methionine and cysteine [27]. Therefore, they have to be mixed to complement each other in the formulation of adequate diets with desirable levels of amino acids.

The protein value of baobab leaves from Kordofan was assessed on the bases of protein concentration, amino acids profile, indispensable amino acids score (IAAS) and protein digestibility corrected indispensable amino acids level (PDCIAAL). The average protein concentration in baobab leaves from $\mathrm{N}$ - and $\mathrm{W}$-Kordofan did not depict any significant ( $>0.05$ ) difference (Table 3). The mean values of the samples collected from ten villages in the two districts were $14.76 \%$ DM (dry matter) basis. Baobab leaves are better than cereals in protein content (barley 10\%; corn 10.3\%; rice 8.5\%; sorghum $12.4 \%$; wheat $10-13.4 \%$ ), but they are not as good as legumes (peas $19.8 \%$; lentils $21.5 \%$; chickpeas $21.5 \%)[28,29]$.

The amino acids profile of the proteins from N-Kordofan, exhibited better quality than those from W-Kordofan (Table 3). Except for the sulfur containing amino acids (cysteine and methionine = SAAs), valine and tryptophan, the concentration of the other amino acids in the proteins of the samples collected from $\mathrm{N}$ - Kordofan were significantly $(\mathrm{p}<0.05)$ higher than those from W-Kordofan. In a similar study with baobab leaves from central and West Africa, isoleucine and leucine were higher (5.7\%, 6.3\%), tryptophan was lower (1.5\%) whereas the concentration of the other amino acids was comparable to that of the leaves from Kordofan [30].

Table 3. Crude protein (\%DM) and amino acid profile (g/100CP) of baobab leaves from Kordofan

\begin{tabular}{|c|c|c|c|c|c|}
\hline \multirow{2}{*}{$\frac{\text { Protein/amino acids }}{\text { Crude Protein }}$} & \multirow{2}{*}{$\frac{\text { N-Kordofan }}{14.8 \pm 0.13}$} & \multirow{2}{*}{$\begin{array}{c}\text { W-Kordofan } \\
14.73 \pm 0.3\end{array}$} & \multirow{2}{*}{$\frac{\text { Egg * }}{\text { g/100gCP }}$} & \multicolumn{2}{|c|}{ IAAS** } \\
\hline & & & & N-Kordofan & W-Kordofan \\
\hline Lysine & $5.41 \pm 0.04 \mathrm{a}$ & $5.08 \pm 0.04 \mathrm{~b}$ & 6.98 & 0.78 & 0.73 \\
\hline Leucine & $4.91 \pm 0.05 \mathrm{a}$ & $4.53 \pm 0.06 \mathrm{~b}$ & 882 & 0.56 & 0.51 \\
\hline Isoleucine & $4.91 \pm 0.05 \mathrm{a}$ & $4.53 \pm 0.06 \mathrm{~b}$ & 6.29 & 0.78 & 0.72 \\
\hline Histidine & $2.19 \pm 0.01 \mathrm{a}$ & $2.04 \pm 0.02 \mathrm{~b}$ & & & \\
\hline Cystine & $1.31 \pm 0.007$ & $1.29 \pm 0.006$ & 2.43 & 0.54 & 0.53 \\
\hline Methionine & $1.78 \pm 0.02$ & $1.69 \pm 0.02$ & 3.36 & 0.53 & 0.50 \\
\hline Valine & $6.9 \pm 0.04$ & $6.65 \pm 0.13$ & 6.85 & 1.01 & 0.97 \\
\hline Arginine & $5.44 \pm 0.04 \mathrm{a}$ & $4.9 \pm 0.06 \mathrm{~b}$ & & & \\
\hline Tyrosine & $3.55 \pm 0.03 \mathrm{a}$ & $3.26 \pm 0.03 \mathrm{~b}$ & 4.16 & 0.85 & 0.78 \\
\hline Tryptophan & $2.32 \pm 0.01$ & $2.28 \pm 0.01$ & 1.49 & 1.56 & 1.46 \\
\hline Phenylalanine & $5.96 \pm 0.03 \mathrm{a}$ & $5.6 \pm 0.03 \mathrm{~b}$ & 5.73 & 1.04 & 0.98 \\
\hline
\end{tabular}

**IAAS = Indispensable amino acids score; *FAO (34) Different letters in the same line signify significant (p<0.05) differences.

Despite the outstanding concentration of tryptophan, the essential amino acids profile of baobab leaves was inferior to that of chicken egg, the common reference protein for quality [31]. In conditions when the protein consumed is deficient in any one of the indispensable amino acid, the efficiency of protein utilization declines, the synthesis of body-proteins slows down, the available amino acids could be deaminated, the amide component could be wasted as urea while the carbon skeleton could be reutilized, stored or oxidized to yield energy [32]. As a consequence, muscular weakness, cognitive retardation, and susceptibility to infection could follow [33]. Quality protein is additionally essential for proper utilization of minerals because of its role as the supplier of indispensable amino acids for the synthesis of enzymes that contain or involve minerals as prosthetic component or as their co-factor in metabolic and physiological 
processes of the muscular, circulatory, nervous and endocrine systems. That is why it is prudent to attach indices of protein quality in characterizing food ingredients.

A valid measure of protein quality includes the comparison of the concentration of indispensable amino acids in the test protein (in food, in baobab leaves) with that of reference protein (egg protein, milk protein) giving the indispensable amino acids score (IAAS) [34]. Accordingly, the baobab leaves from $\mathrm{N}$ - and $\mathrm{W}$-Kordofan (Table 3) proved to be adequate in the aromatic amino acids (AAAs = tyrosine, phenylalanine), but poor sources of leucine, cystine and methionine, and moderate sources of lysine and isoleucine.

A method based on the comparison of the amino acids content of food with the amino acid requirement of human beings is also accepted as suitable approach for assessing the protein quality of foodstuffs. As indicated in Figure 2, baobab leaves are rich in isoleucine, aromatic amino acids and tryptophan to a level that they can on their own meet the daily requirement of an adult person if provided at $25 \%$ of the daily diet. This in agreement with the IAAS of baobab leaves is indicated in Table 3.

The measurement of protein quality based on amino acid profile may fail to account for the adverse effects of antinutritional factors including trypsin-inhibitors and hemagglutinins in legumes, and phytic acids in cereals [35]. Both legumes and cereals as well as baobab leaves are high in tannins, lingo-cellulose and phytic acid, the molecules that negatively influence the bioavailability or efficient utilization of proteins in a diet [36]. Therefore, it was found logical to use a correction factor for the discrepancy that could result from the antinutritional factors.

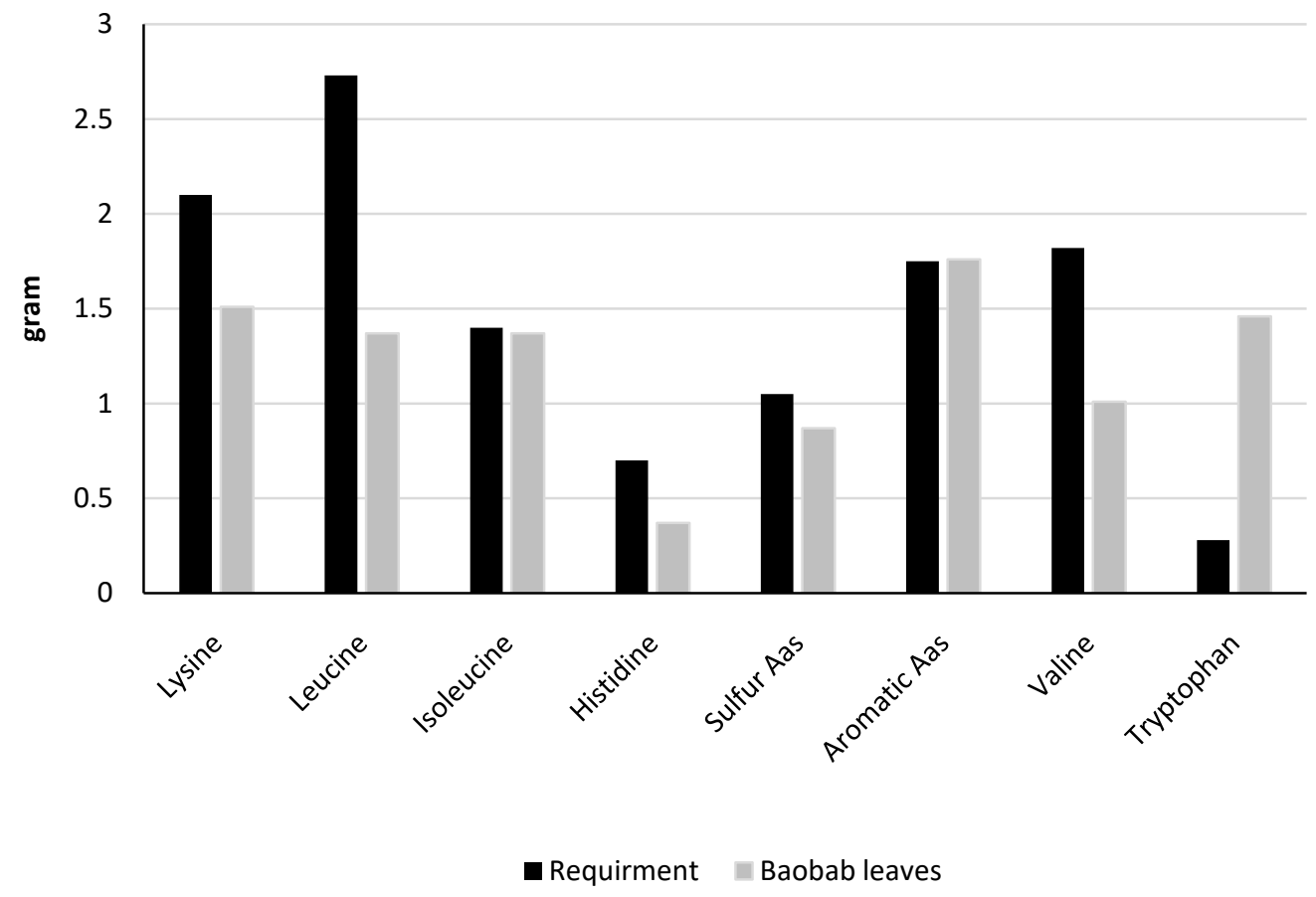

Figure 2. Indispensable amino acids requirements (g/d) by adults and the provision by dry baobab leaves that constitute $25 \%$ of a daily diet (Note that the digestibility of $\mathrm{CP}$ is not considered).

Protein digestibility is a simple and scientifically sound correction factor for routine assessment of protein bioavailability [37]. In developing countries, traditional diets are often characterized by protein digestibility that varies between 54 and $78 \%$ [38]. The average in-vitro digestibility of crude protein of cereals is estimated at $60 \%$ [39]. The indispensable amino acids content of each of baobab leaves, cereals and legumes was multiplied by the coefficient 0.6 to find out the protein digestibility corrected indispensable amino acids level (PDCIAAL). With due consideration to the daily energy requirement $(2,800 \mathrm{kcal})$ of a middle age adult $(70 \mathrm{~kg}$ body weight) and moderate physical activity level $(\mathrm{PAL}=$ 1.6), a diet was formulated using the common food ingredients (cereals and legumes) in Kordofan and dry baobab leaves. The diet was designed to consist of $60 \%$ cereals $20 \%$ legumes and $20 \%$ baobab leaves. The focus was on the comparison between protein digestibility corrected indispensable amino acids levels (PDCIAAL) of the components of daily diet with the corresponding daily requirement by an adult man.

Baobab leaves make only 1/3 of the cereals in the diet but they contribute more bio-accessible lysine, the amino acid that is most limiting in cereals (Table 4). They also supply the same amount of bio-accessible valine as the cereals. The legumes, which only make $1 / 5$ of the daily diet, supply about 2 times more bio-accessible lysine than either cereals or baobab leaves. 
Table 4. The average PDCIAAL (g) in the daily diet (2,800 kcal) consisting of $60 \%$ cereals, $20 \%$ legumes and $20 \%$ baobab leaves

\begin{tabular}{cccccc}
\hline Food & Lucien & Lysine & Valine & SAAs & Histidine \\
\hline Baobab leaf & 0.5 & 0.6 & 0.7 & 0.2 & 0.2 \\
*Legumes & 0.8 & 1.1 & 0.5 & 0.4 & 0.4 \\
*Cereals & 2.9 & 0.5 & 0.7 & 0.4 & 0.6 \\
\hline
\end{tabular}

*Calculated based on the data from references 31, 41, 42 and 43.

The cereals contribute about 2 times more bio-accessible leucine than that of the sum of both legumes and baobab leaves. The food diversity is in any way essential for the purpose of complementarity in at least satisfying the requirement for indispensable amino acids, not to mention the cheaper cost of baobab leaves and its relatively higher content of calcium, iron and beta-carotene, the nutrients that are limiting in standard diets of east Africa.

For practical purposes, the diet formulated to satisfy the requirement for indispensable amino acids and the contribution of baobab leaves, cereals and legumes were compared with the daily requirement of an adult. The results are summarized in Figure 3.

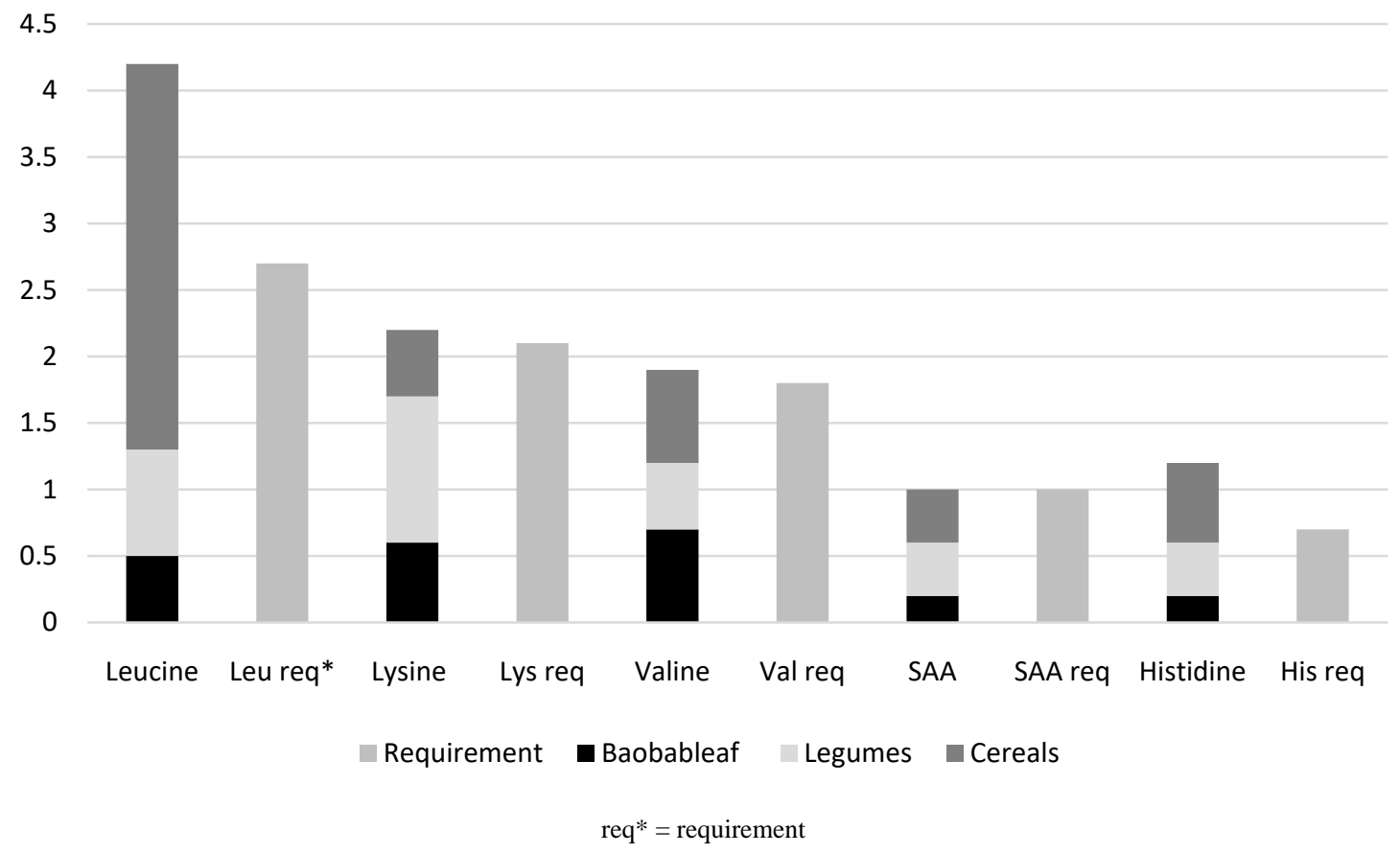

Figure 3. Fulfilling the daily requirement of an adult for indispensable amino acids by a daily diet (600 $\mathrm{g}$ air-dry) consisting of $20 \%$ baobab leaves, $60 \%$ cereals (maize, sorghum), $20 \%$ legumes (lentils, beans or chickpeas).

The diet that was formulated from baobab leaves, cereals and legumes to be consumed either in the form of porridge containing all ingredients; or stew/soup of the mixture of baobab leaves and legumes and some porridge of cereals, could satisfy the requirements for all limiting amino acids. Leucine, lysine and SAAs made $155 \%$, 105\% and 100\% of the requirement respectively. Baobab leaves made $20 \%$ of the diet but they contributed 37\% valine, 27\% lysine and $20 \%$ SAAs. It is to be noted that without the inclusion of baobab leaves, the requirements for lysine, valine and SAAs would not be met. Substitution with legumes is thinkable but the cost-benefit analysis favors baobab leaves; they can be simply collected from village forests or own trees in $\mathrm{N}$ - and $\mathrm{W}$-Kordofan. It is wise to mix them in the given proportion for purposes of diversification and the complementarity in balancing a diet not only in quality protein but also in other limiting nutrients like calcium, iron, magnesium, beta-carotene. Baobab leaves outstrip all food ingredients in calcium (2.85 g/100 gDM), magnesium (0.55 g/100 gDM) and iron (42.2 mg/100 gDM) [16]. These minerals count to the micro-nutrients that cause hidden hunger among 2 billion people in the world [40].

\section{Conclusion}

The in-vitro bioavailability of variable minerals in baobab leaves was different. Except for magnesium (59.4\%) the values of the other minerals were variably low ranging from $5.3 \%$ to $40 \%$. Iron proved to be the least absorbable mineral. The in-vitro bioavailability of $\mathrm{Ca}, \mathrm{Mg}, \mathrm{Zn}$ and $\mathrm{Cu}$ correlated directly with each respected level that is exposed to 
in-vitro digestion; the level of the concerned minerals did not exceed the recommended daily allowance. Iron and manganese did not exhibit similar tendencies, and district effects influenced their in-vitro bioavailability implicating the need for further investigations on confounding factors.

The crude protein value of baobab leaves was more than cereals but less than that of legumes. In general, the protein quality could be classified as moderate because of the amino acids profile that reflected rich amount of tryptophan and aromatic amino acids, medium level of lysine, isoleucine and tyrosine, but poor content of leucine and SAAs. A mixed daily diet (600g air-dry) consisting of cereals (60\%), legumes (20\%) and baobab leaves (20\%) proved complementarity in satisfying the requirement for amino acids.

\section{Declaration}

The authors declare that there is no conflict of interest regarding the publication of this paper.

\section{Acknowledgement}

We are thankful for the cooperation of the administration of the Kordofan University, El-Obeid, Sudan and particularly for the contribution of Dr. Muneer Siddig, who acted as local liaison officer and participated in sample collection.

We highly appreciate the collaboration of Prof. Dr. Duering, R-A and Ms. Schneidenwind, E. of the Institute of Soils Science and Soil Conservation, Justus-Liebig-University Giessen, Giessen, Germany, in the mineral analysis of the baobab leaves soluble extract and respective dialysate.

The contribution of the Institute of Agricultural Engineering, Tropics and Subtropics Group, University Hohenheim, Stuttgart, Germany in the analysis of protein and amino acids is worth mentioning and appreciating.

We thankfully acknowledge the funding of the research project by the German Federal Ministry of Food and Agriculture (BMEL) based on a decision of the Parliament of the Federal Republic of Germany via the Federal Office for Agriculture and Food (BLE), grant number FKZ 2813FSNU08. The sponsors did not have any role in planning and implementation of the research project and the interpretation of results and composition of this article.

Thanks, is dully extended to the mother institution Justus-Liebig University of Giessen for the provision of necessary infrastructures, facilities, technologies, and administrative support.

\section{References}

[1] Glew, R. H., VanderJagt, D. J., and Glew, R. S. (2007). Plant foods of West Africa: A Call for Bioavailability Studies. Food, 1(1): 85-87.

[2] Hu, Y., Cheng, Z., Heller, L. I., Krasnoff, S. B., Glahn, R. P., and Welche, R. M. (2006). Kaemferol in red and pinto bean seed coats inhibits iron bioavailability using an in-vitro digestion/human Cacao cell model. J Agric Food Chem., 54: 9254-9261.

[3] Tako, E., Glahn, R. P., Laparra, J. M., Welche, R. M., Lei, X., Kelly, J. D., Rutzke, M. A., and Miller, D. D. (2009). Iron and zinc bioavailability to pigs from red and white beans are similar. J Agric Food Chem., 57: 3134-31-40.

[4] Habte, T. Y. and Krawinkel, M. B. (2017). Metaphysical Analysis of the Nutritional and Therapeutic Value of Baobab. J Nutr Health Sci., 4(3): 306-312.

[5] Gonzalez-Gallego, J., Garcia-Mediavilla, M. V., Sanchez-Campos, S., and Tunon, M. J. (2010). Fruit phenols, immunity and inflammation. Br J Nutr., 104(3): s15-s27.

[6] Etcheverry, P., Grusak, M. A., and Fleige, L. E. (2012). Application of in vitro bio-accessibility and bioavailability methods for calcium, carotenoids, folate, iron, magnesium, polyphenols, zinc and vitamins B6, B12, D, E. Physiology, 3(317), 1-22.

[7] Abrams, S. A., Grusak, M. A., Shuff, J., and O’Brien, K. O. (1997). Calcium and magnesium balance in 9-14-y-old children. Am J Clin Nutr., 66(5): 1172-1177.

[8] Nieves, J. W. (2013). Skeletal effects of nutrient and nutraceutical, beyond calcium and vitamin D. Osteoporosis Int., 24: 771-786.

[9] Narva, M., Karkkainin, M., Poussa, T., Lamberg-Allardt, C., and Korpela, R. (2003). Casein phosphopeptides in milk and fermented milk do not affect calcium metabolism acutely in postmenopausal women. J Am Coll Nutr Rev., 68: 333-340.

[10] Coudray, C., Bellanger, J., Vermorel, M., et al. (2003). Two Polyol, Low Digestible Carbohydrates Improve the Apparent Absorption of Magnesium but not of Calcium in Healthy Young Men. J Nutr., 133(1): 90-93.

[11] Goda, T., Yamanda, M., Takase, S., and Hosoya, N. (1992). Effect of malitol intake on intestinal calcium absorption in rat. J Nutr Sci Vitaminol (Tokyo), 38(3): 277-286.

[12] FAO/WHO. (1998). Vitamin and mineral requirements in human nutrition. $2^{\text {nd }}$ edition. Joint FAO/WHO Expert Consultation on Human Vitamin and Mineral Requirement. Bangkok, Thailand. Pp. 64-67.

[13] Waters, M. E., Esfandi, R., and Tsopnio, A. (2018). Potential of Food Hydrolyzed Proteins and Peptides to Chelate Iron and Calcium and Enhance Their absorption. Foods, (10): 172-181. 
[14] Jennings, A., MacGregor, A., Spector, T., and Carzidy, A. (2016). Amino Acids Intakes with Bone Mineral Density and Prevalence of Low Bone Mass in Woman. J Bone Miner Res., 31(2): 326-335.

[15] Fenton, T. R., Lyon, A. W., Eliasziw, M., Tough, S. C., and Hanley, D. A. (2009). Meta-analysis of the effect of the acid ash hypothesis of osteoporosis on calcium balance. J Bone Miner Res., 24(4): 1835-1840.

[16] Habte, T. Y., Suleiman, I., Ahmed, A. E., and Krawinkel, M. B. (2019). The Potential of Baobab Leaves from North- and West Kordofan in Sudan as Mineral Complement of Common Diets. J Nutrition and Food Processing, 2(2). Doi: 1031579/2637-8914/015.

[17] Chadare, F. J. (2010). Baobab (Adansonia digitata L) food from Benin: Composition, processing and quality—Chapter 4-Effect of cooking on invitro solubility of Ca, Fe, Zn and Carotenoids in baobab leaves. Pp. 79-93.

[18] Miller, D. D., Schricker, B. R., Rasmussen, R. R., and Van Campen, D. (1981). An in vitro method for estimation of iron availability from meals. Am J Clin Nutr., 34: 2248-2256.

[19] Wolters, M. G. E., Schreuder, H. A. W., Van den Heuvel, G., Van Lonkhuijsen, H. J., Hermus, R. J. J., and Voragen, A. G. J. (1993). A continuous in vitro method for the estimation of the bioavailability of minerals and trace elements in foods: application to breads varying in phytic acid content. Br J Nutr., 69: 849-861.

[20] Snedecor, G. W. and Cochran, W. G. (1980). Statistical Methods. $7^{\text {th }}$ ed. Ames, IA: Iowa State University Press.

[21] Hurrel, R. F. (2003). Influence of vegetable protein sources on trace element and mineral bioavailability. J Nutr., 133(9): 2973-297.

[22] Sandstrom, B. H., Almgren, A., Kivistoe, B., and Cederblad, A. (1989). Effect of protein and protein sources on zinc absorption in humans. J Nutr., 119(1): 48-53.

[23] Kerstetter, J. E., O’Brien, K. O., Caseria, M., Wall, D. E., and Insogna, K. L. (2005). The Impact of Dietary Protein and Calcium Absorption and Kinetic Measures of Bone Turnover in Woman. J Clin Endocr and Metab., 90(1): 26-31.

[24] Galan, M. G. and Drago, S. R. (2014). Effects of soy protein and calcium levels on mineral bioavailability and protein digestibility from enteral formulas. Plant Foods Hum Nutr., 69(3): 283-289.

[25] Wolfe, R. (2006). The underappreciated role of muscle in health and disease. Am J Clin Nutr., 84: 475-482.

[26] Kang, J. (2012). Nutrition and Metabolism in Sports, Exercise and Health. Published by Routledge, $7113^{\text {rd }}$ Avenue, New York, NY 10017. Pp. 44-48.

[27] Hagan, N. D., Tabe, L. H., Molving, L., and Higin, T. J. V. (2002). Modifying the Amino Acid Composition of Grains Using Gene Technology. Plant Biotechnology, pp. 305-308.

[28] Rajnincova, D., Spalekova, A., Galova, Z., and Romanova, K. (2019). The protein profile of cereals, pseudo-cereals and legumes. J Food Sci Techno., 7(1): 49-53.

[29] Hacker, L. R. (1983). Cereals Proteins in Human Nutrition. In: Amino Acids Composition and Biological Value of Cereal Proteins. Proceedings of the International Association for Cereal Chemistry Symposium. Budapest, Hungary, May 31-June 1, 1983 pp. 81-104.

[30] Yazzi, D., Van der Jagt, D. J., Pastuszya, A., Okdo, A., and Glew, R. H. (1994). The amino acids and mineral content of baobab (Adanosin digitata L.) leaves. J Food Comp Analysis, 7: 189-193.

[31] McKevith, B. (2004). Nutritional aspects of cereals. British Nutrition Foundation, Nutrition Bulletin, 29: 111-142.

[32] Maloni, L. and Mirand, P. P. (2003). Type and timing of protein feeding to optimize anabolism. Curr Opin Clin Nutr Metab Care, 6(3): 301-306.

[33] Kemp, J. (2012). Nutrition and Metabolism in Sports, Exercise and Health. Published by Routledge. $7113^{\text {rd }}$ Avenue, New York NY10017, pp. 44-48.

[34] FAO. (2013). Dietary protein quality in human nutrition. A report of an FAO Expert Consultation, 31 March-2 April, 2011. Auckland, New Zealand Chap., 2: 3-17.

[35] Sarwar, G. (1997). The Protein Digestibility Corrected Amino Acids Score Method Overestimates Quality of Proteins Containing Antinutritional Factors and of Poorly Digestible Protein Supplements with Limiting Amino Acids in Rats. J Nutr., 127(5): 758-764.

[36] Rehman, Z. and Shah, W. H. (2005). Thermal heat processing effects on antinutrient s, proteins and starch digestibility of food legumes. Food Chemistry, 91: 327-331.

[37] FAO/WHO. (1991). Protein quality evaluation: Report of the joint Food and Agriculture Organization and World Health Organization Expert Consultation. FAO Food and Nutrition, Paper 51, Rome, Italy.

[38] Joye, I. (2019). Protein digestibility of cereal products. Foods, 8: 199-213.

[39] Afify, A. E.-M. M. R., El-Beltagi, H. S., Abd El-Salam, S. M., and Omran, A. A. (2012). Protein Solubility, Digestibility and Fractionation after Germination of Sorghum Varieties. PLoS ONE, 7(2): e31154. https://doi.org/10.1371/journal.pone.0031154 accessed 20.3.2020.

[40] WHO-FAO. (2014). Better nutrition better lives. WHO and FAO announce Second International Conference on Nutrition 
(ICN2). 19-21 November, 2014, Rome, Italy.

[41] Bressani, R., Elias, L. G., and Navarrete, D. A. (1961). Nutritive Value of Central American Beans IV. The essential amino acids content of samples of black beans, red beans, rice beans and cowpeas of Guatemala. Food Sci., 2(5): 525-528.

[42] Kaharaman, A. (2016). Nutritional Components and Amino Acids in Lentil Varieties. Selenk J Agr Food Sci., 30(1): 34-38.

[43] Saleh, A., Alajaji, Tarek A., El-Adawy. (2006). Nutritional composition of chickpea as affected by microwave cooking and other traditional cooking methods. J Food Comp Analysis, 1-7. 